\title{
An Analysis of Bodri Watershed Governance System
}

\author{
Husna Fauzia ${ }^{1,2^{*}}$, Rukuh Setiadi ${ }^{3}$, and Satya Budi Nugraha ${ }^{4}$ \\ ${ }^{1}$ Master Student of Urban and Regional Planning, Faculty of Engineering, Diponegoro University, Semarang - Indonesia \\ ${ }^{2}$ Office of Public Works Water Resources and Spatial Planning, Central Java Province, Semarang - Indonesia \\ ${ }^{3}$ Department of Urban and Regional Planning, Faculty of Engineering, Diponegoro University, Semarang - Indonesia \\ ${ }^{4}$ Department of Geography, Faculty of Social Sciences, Universitas Negeri Semarang, Indonesia
}

\begin{abstract}
Watershed management needs collaboration and program integration from all stakeholders including government and non-government institutions, as well as communities. Despite the existent of a number of regulatory frameworks, there are various problems in watershed management that need to be systematically diagnosed for future improvement. This paper focuses on Bodri Watershed, which stretches through three regencies (e.g. Temanggung, Semarang and Kendal Regencies) and has a vital role not only in the ecological but also socio-economic life of the surrounding communities. The paper aims to evaluate the current conditions of the watershed through governance lens. This paper employs Governance System Analysis (GSA) approach and mainly uses qualitative method for data collection. The paper finds that there is lack of coordination, integration, synergy and synchronization in the application of knowledge, connectivity and capacity for participation of related stakeholders to the management of the Bodri Watershed. This situation explains environmental problems and ecosystem damages in the Bodri Watershed area. These problems include massive land conversion, erosion, landslides, sedimentation, and flooding and drought in the rainy and dry seasons respectively.
\end{abstract}

Keywords: watershed management; Bodri Watershed; Governance System Analysis (GSA).

\section{Introduction}

Based on Presidential Regulation No. 12/ 2012 concerning Determination of River Areas, Central Java Province consists of 202 watersheds [1]. Bodri is one of the degraded watersheds in Central Java that is categorized in the critical condition. Identification of the critical status of watershed was carried out by the Ministry of Forestry in 2009 by categorizing the Bodri Watershed as one of the 108 watersheds which considered as critical. This was supported by the Central Java Regional Regulation No. 15/2014 concerning Management of Watersheds in the Central Java Region [2] which states that the Bodri Watershed was included in the watersheds which should restore their carrying capacity.

The critical condition could be proven through the occurrence of land conversion causing deterioration on environmental quality. A significant amount of land use in the watershed has changed from a buffer zone to the cultivation area. Based on the Bodri Watershed performance monitoring and evaluation report [3], the size of protected forests was only around $25 \%$ of the total area of the Bodri Watershed. One of the crucial factors that triggered land conversion in the Bodri Watershed is an increase in population and socioeconomic activities of the local community. Population pressure in the Bodri Watershed area was relatively high, with score $>2$. This means local residents are very dependent on processing land to fulfill their daily lives [4].

Increasing the number of residents causes uncontrolled land conversion and causes negative effects on the environment $[5,6]$. In order to overcome the problems, it is necessary to integrate management in a single river basin management from upstream to downstream $[7,8]$.

Besides the physical problems as mentioned above, there are indications of the lack of integration of policies between stakeholders involved in the Bodri Watershed management. In practice, some problems that arise include 'silo' or locally known as sectoral ego. It means that putting emphasis on the interests of each sector compared to the integration and collaboration of policies between sectors. In addition, lack of coordination between related stakeholders persists has resulted in conflicts between sectors and between regions leading to ineffectiveness in watershed management. This is aligned to Tarlock's opinion [9] stating that the absence of inter-governmental coordination and cooperation may lead to ineffective watershed management as well as conflicts between sectors/activities.

This paper aims to assess the current state of governance system in Bodri Watershed management based on the Governance System Analysis (GSA) approach by analyzing three important themes: (i) the application of knowledge, (ii) the relationships or connectivity between stakeholders, and (iii) the capacity

* Corresponding author: husnafauzia@gmail.com 
of stakeholders participate in Bodri Watershed management.

\section{Research Method}

Fig. 1 shows research area of this study, Bodri Watershed. It also a working area of Bodri Watershed Management Authority in the Central Java Province. The area consists of jurisdiction of three government regencies, namely Temanggung, Semarang, and Kendal.

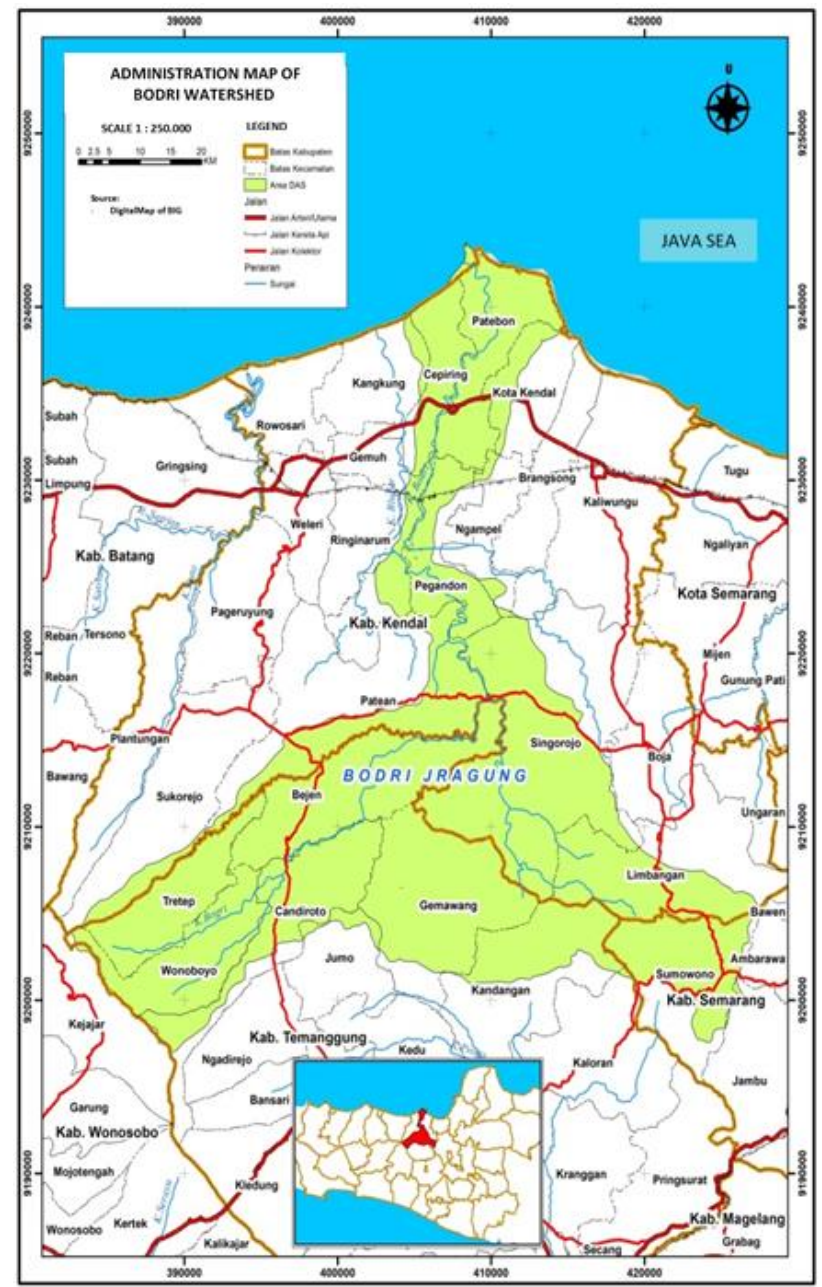

Fig. 1. Administration Map of Bodri Watershed

The population in this study was stakeholders related to the management of the Bodri Watershed at various levels, which consists of 21 stakeholders. These stakeholders are: (i) central government level: Watershed Management Authority (BPDAS) Pemali Jratun and River Basin Management Authority (BBWS) Pemali Juana; (ii) provincial government level, namely: Public Work Agency for Water Resource and Spatial Planning (PUSDATARU), Environmental and Forest Agency (DLHK), Planning and Development Board (BAPPEDA), Infrastructure and Water Resource Bureau (Biro ISDA), and Food and Agriculture Agency (DPP); (ii) regency government level organisations that responsible for the environmental management, development planning, agriculture, public works, and foods as well as fisheries, (iv) non-government institution: Central Java Watershed Forum (FORDAS Jateng) and Bodri Watershed Forum (FORDAS Bodri).

This study employs a qualitative method with the Governance System Analysis (GSA) approach [10, 11]. The method of data collection was done by conducting in-depth interviews related to the application of knowledge, stakeholder relations/connectivity and the capacity of stakeholders in Bodri Watershed management.

\section{Result and Discussion}

\section{1 Condition of Bodri Watershed}

The current condition of the Bodri Watershed is alarming. The watershed has a critical area of $14,033.51$ hectares or approximately $25 \%$ of the total area of the watershed, with the most degraded area is in the upstream [12]. Agricultural activities that have not implemented soil conservation in the management of their land, are the main cause of this condition. Then, it has caused a decrease in the quality of the environment and ecosystems in the watershed. Figure 2 shows some situations in the upstream of the watershed, while Figure 3 shows some areas in Bodri Watershed which is prone to landslides, erosion, sedimentation, and flood in the rainy season, and drought in the dry season.

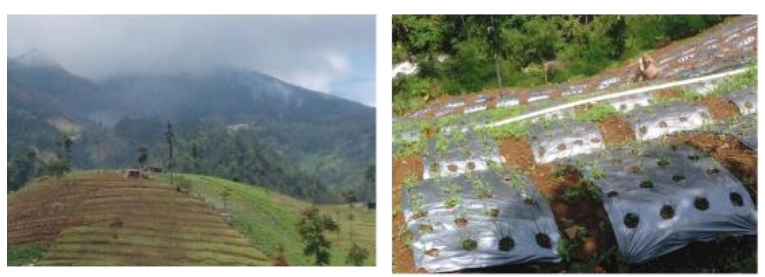

Fig. 2. The Condition of Upstream Area of Bodri Watershed
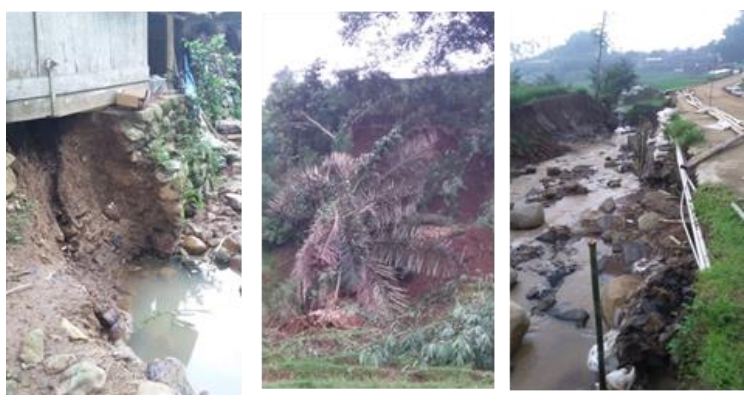

Fig. 3. Landslide in Purwosari Village, Wonoboyo District, Temanggung Regency

\section{2 Application of Knowledge in Bodri Watershed Management}

The application of knowledge in Bodri Watershed management has not been well implemented. It could be seen from the gap of studies/research conducted by the stakeholders related to Bodri Watershed management. Research outputs should be the basis of the application of stakeholders' practice related to the management of the Bodri Watershed. It is expected that the research 
findings are applied in the implementation of programs/activities and should be conducted by each stakeholder. In addition, there is still a lack of training related to the Bodri Watershed management, for all stakeholders.

\section{3 Stakeholder Connectivity in the Management System of Bodri Watershed}

The stakeholders related to the Bodri Watershed management have established a forum (TKPSDA and Forum DAS) which consists of government and nongovernment elements. In the forum, relevant stakeholders have been given access to deliver problems related to Bodri Watershed management. With the existence of the forum, it is hoped that a strategy could be formulated to become a program or activity of each stakeholder in carrying out their duties related to the Bodri Watershed management. In practice, each stakeholder runs on its own. There has been weak coordination and synergy to conduct their tasks in managing the Bodri Watershed. Sectoral ego is still found and there is overlapping authority between stakeholders so that the planned arrangements do not operate as expected. Shortly, connectivity between stakeholders in the Bodri Watershed management system has not run optimally.

\section{4 Stakeholder Capacity in Bodri Watershed Management}

Relevant stakeholders in the Bodri Watershed management have had decision-making capacity in terms of the capacity to prepare their vision, mission, and objectives. They have been involved in the initial preparation of the Bodri Watershed's vision, mission, and objectives. The stakeholders also have the capacity to develop strategies but there are obstacles that must be addressed immediately, especially related to the inconsistency of participants who represent in the forum. For example, staff who represent the forum keep changing due to availability and task rotation. They do not strategic position in bureaucracy so that important decision or records in the forum could not be implemented properly. In addition, stakeholders at Bodri Watershed are perceived to have lack capacity in terms of research and assessment, implementation capacity/ strategy implementation, and monitoring, evaluation, and review. This is caused by several factors, including a limited budget, collided with authority, not being the main task of each stakeholder, un-functioned Bappeda as the leading sector and the fact that the strategy formulation has not been included in the mid-term development plan (RPJM) as a performance indicator of each related stakeholder. Table 1, explain the detailed result of GSA.

Table 1. Matrix of GSA

\begin{tabular}{|c|c|c|c|}
\hline Aspects & Knowledge Application & Connectivity & Participant Decision Capacity \\
\hline $\begin{array}{c}\text { Vision and } \\
\text { Objective } \\
\text { Setting }\end{array}$ & $\begin{array}{l}\text { - Formulation of vision and mission } \\
\text { in Bodri watershed management } \\
\text { has not been integrated between } \\
\text { sectors, it was partially based on } \\
\text { technical guidelines from the } \\
\text { relevant ministries }(-) \\
\text { - Setting of Bodri Watershed } \\
\text { management vision and objective } \\
\text { is in line with the objectives of } \\
\text { integrated watershed } \\
\text { management }(+)\end{array}$ & $\begin{array}{l}\text { - There is a watershed } \\
\text { management forum involving } \\
\text { multi stakeholders, namely } \\
\text { Forum TKPSDA and Forum } \\
\text { DAS (+) } \\
\text { Vision and objective setting } \\
\text { process have not involved all } \\
\text { stakeholders related to } \\
\text { watershed management }(-)\end{array}$ & 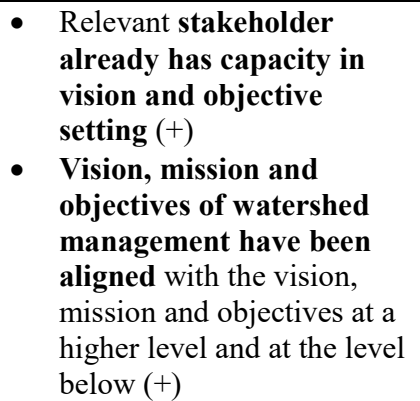 \\
\hline $\begin{array}{c}\text { Research } \\
\text { and } \\
\text { Assessment }\end{array}$ & $\begin{array}{l}\text { - The research has not been } \\
\text { conducted by stakeholder who in } \\
\text { charge to manage Bodri Watershed } \\
\text { (DLHK Central Java Province) (-) } \\
\text { - There is third party involvement } \\
\text { in Bodri watershed management } \\
(+)\end{array}$ & $\begin{array}{l}\text { - Not all stakeholders which } \\
\text { involved in Bodri Watershed } \\
\text { management have conducted } \\
\text { research/studies (-) } \\
\text { - The study and research were } \\
\text { still sectoral (-) } \\
\text { There was no joint } \\
\text { research/studies which } \\
\text { conducted by relevant } \\
\text { stakeholders (-) } \\
\text { The research/study result had } \\
\text { not become a reference for } \\
\text { relevant stakeholders in the } \\
\text { Bodri watershed management } \\
\text { (-) }\end{array}$ & $\begin{array}{l}\text { - Stakeholders related to the } \\
\text { Bodri Watershed } \\
\text { management do not have } \\
\text { the capacity yet to conduct } \\
\text { research and studies }(-)\end{array}$ \\
\hline $\begin{array}{l}\text { Strategy } \\
\text { Develop- } \\
\text { ment }\end{array}$ & 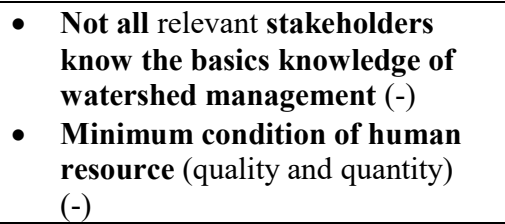 & $\begin{array}{l}\text { There has been accessed to } \\
\text { deliver problems in each } \\
\text { sector so that it will be } \\
\text { formulated as the Bodri } \\
\text { Watershed management strategy } \\
(+)\end{array}$ & 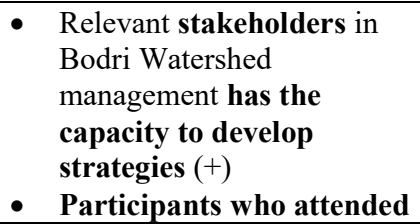 \\
\hline
\end{tabular}




\begin{tabular}{|c|c|c|c|}
\hline Aspects & Knowledge Application & Connectivity & Participant Decision Capacity \\
\hline & $\begin{array}{l}\text { Training for stakeholder capacity } \\
\text { building is still limited (-) } \\
\text { - } \\
\text { Strategy development is often not } \\
\text { suitable (-) } \\
\text { - In the strategy development } \\
\text { process, has not referred to the } \\
\text { prepared planning documents (-) } \\
\text { Documents that have been } \\
\text { developed (RPDAST) has not } \\
\text { been internalized into each } \\
\text { planning and development plans } \\
\text { (RTRW and RPJMD) (-) }\end{array}$ & $\begin{array}{l}\text { - There is active involvement of } \\
\text { stakeholders regarding to } \\
\text { strategy development that } \\
\text { needed for Bodri Watershed } \\
\text { management }(+)\end{array}$ & $\begin{array}{l}\text { the Bodri Watershed } \\
\text { management forum was } \\
\text { always changed and were } \\
\text { not authorized to make } \\
\text { decisions (-) } \\
\text { Human resource quality is } \\
\text { uneven in each stakeholders } \\
(-)\end{array}$ \\
\hline $\begin{array}{c}\text { Strategy } \\
\text { Implemen- } \\
\text { tation }\end{array}$ & $\begin{array}{l}\text { There is community involvement } \\
\text { in Bodri Watershed management } \\
\text { - }+ \text { Mutual cooperation and prohibition } \\
\text { on cutting down banyan trees as a } \\
\text { form of local wisdom in the Bodri } \\
\text { watershed management (+) } \\
\text { - Society still have higher interest } \\
\text { to short economic profit (-) } \\
\text { There is already the } \\
\text { implementation of technology } \\
\text { /software systems in the } \\
\text { management of the Bodri } \\
\text { Watershed, but not yet thoroughly } \\
\text { in all relevant stakeholders (+/-) } \\
\text { Green open space in the Bodri } \\
\text { Watershed is less than 30\% which } \\
\text { is not in accordance with existing } \\
\text { regulations (Central Java Regional } \\
\text { Regulation No. } 6 \text { of } 2010 \\
\text { concerning planning documents } \\
\text { (RTRW) of Central Java } 2009- \\
\text { 2029), namely a minimum number } \\
\text { of RTH of } 30 \% \text { of the watershed } \\
\text { area (-) } \\
\text { The implementation of Bodri } \\
\text { Watershed management still } \\
\text { does not refer to spatial plans and } \\
\text { patterns of water resources } \\
\text { management. This is not in } \\
\text { accordance with Government } \\
\text { Regulation No. } 37 \text { of } 2012 \\
\text { concerning watershed management } \\
\text { (-) }\end{array}$ & $\begin{array}{l}\text { - The formulation of the strategy } \\
\text { that becomes a collective } \\
\text { agreement has not been } \\
\text { implemented by all relevant } \\
\text { stakeholders (-) } \\
\text { - There are budget constraints in } \\
\text { implementing the strategy (-) } \\
\text { - There is an understanding that } \\
\text { the strategy which produced is } \\
\text { not the main task of the related } \\
\text { stakeholders (-) } \\
\text { - Minimum role of Bappeda of } \\
\text { Central Java Province as a } \\
\text { leading sector in the watershed } \\
\text { management (-) } \\
\text { - The absence of synergy } \\
\text { between stakeholders in Bodri } \\
\text { Watershed management (-) } \\
\text { - There are still sectoral egos in } \\
\text { each parties (-) } \\
\text { - There is overlapping policy (-) } \\
\text { - The absence of } \\
\text { synchronization between } \\
\text { regulations related to watershed } \\
\text { management (-) }\end{array}$ & $\begin{array}{l}\text { - The strategy is still in the } \\
\text { form of plan / design, has } \\
\text { not been implemented (-) } \\
\text { Relevant stakeholders to } \\
\text { Bodri Watershed } \\
\text { management do not have } \\
\text { yet the capacity to } \\
\text { implement the strategies } \\
\text { because of several factors } \\
\text { including budget } \\
\text { constraints, understanding } \\
\text { of some stakeholders that } \\
\text { the strategy is not the main } \\
\text { task force, lack of leading } \\
\text { sector role in watershed } \\
\text { management and the fact } \\
\text { that the strategy has not } \\
\text { been incorporated into } \\
\text { RPJM which become } \\
\text { performance indicators of } \\
\text { each related stakeholder (-) }\end{array}$ \\
\hline $\begin{array}{l}\text { Monitoring } \\
\text { Evaluation } \\
\text { and Review }\end{array}$ & $\begin{array}{l}\text { The monitoring that has been } \\
\text { conducted is in accordance with } \\
\text { the mechanisms and procedures for } \\
\text { monitoring based on Regulation of } \\
\text { Minister of Forestry No. P. } 61 / \\
\text { Menhut-II /2014, concerning } \\
\text { Monitoring and Evaluation of } \\
\text { Watershed Management. ( }+ \text { ) } \\
\text { The implementation of } \\
\text { monitoring time has not referred } \\
\text { to regulations, it should be } \\
\text { conducted periodically at least } \\
\text { once a year, but it is still carried } \\
\text { out once in a period of } 4 \text { years. }(-)\end{array}$ & $\begin{array}{l}\text { There are no monitoring, } \\
\text { evaluation and review } \\
\text { activities conducted jointly by } \\
\text { stakeholders related to Bodri } \\
\text { Watershed management (-) } \\
\text { Monitoring activities are still } \\
\text { sectoral (-) }\end{array}$ & 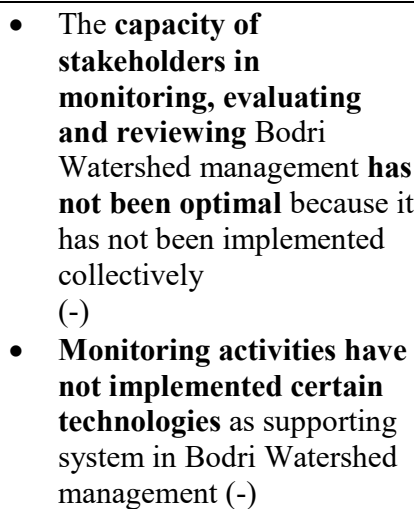 \\
\hline
\end{tabular}

Explanation:

$(+)=$ Positive findings in Bodri Watershed management that need to be maintained

$(-)=$ Negative findings in Bodri Watershed management that need to be improved 


\section{Conclusion}

Based on the analysis results of the Bodri Watershed management using the governance system analysis (GSA) approach indicate that the Bodri watershed management has not been effective and efficient because there are still many weaknesses in almost all structures and functions in a GSA perspective. Ineffective and efficient Bodri watershed management, among others, was indicated by the lack of coordination among related stakeholders, causing overlapping policies; there are still sectoral ego in the implementation of strategy; there is no regular study/research to support Bodri watershed management; lack of commitment related stakeholders in carrying out the implementation of the strategies that have been formulated; and evaluation, review, and monitoring activities are still not routinely carried out by the relevant stakeholders. Therefore, general efforts are still needed to improve coordination, integration, synergy, and synchronization between stakeholders related to Bodri Watershed management both in the planning, implementation, control, monitoring and evaluation stages for better management of Bodri Watershed.

\section{Acknowledgment}

This research was supported and funded by the Minister of Public Work of Indonesia through the scholarship of master student in MPWK UNDIP, Semarang.

\section{References}

1. Presidential Decree No. 12, River Basin Determination, Indonesia (2012)

2. Regional Regulation of Central Java Province No. 15, Watershed Management in the Central Java Province, Indonesia (2014)

3. BPDAS, Final Report on Monitoring and Evaluation of Bodri Watershed Management, BPDAS Pemali Jratun (2016)

4. I. Sriyana, Evaluation of watershed carrying capacity for watershed management (A case study on Bodri watershed, Central Java, Indonesia), 05003, 1-10 (2018)

5. S. Kundu, D. Khare, A. Mondal, Landuse Change Impact on Sub-Watersheds Prioritization by Analytical Hierarchy Process (AHP), Ecol. Inform. (2018)

6. X. Zhang, W. Cao, Q. Guo, S. Wu, Effects of Landuse Change on Surface Runoff and Sediment Yield at Different Watershed Scales on the Loess Plateau, Int. J. Sediment Res. 25(3), 283-293 (2010)

7. R.J. Polie, V. Dermawan, A Study of Watershed Management in Conservation of Water Resources (Case Study: Bone Watershed of Gorontalo Province), Tek. Pengair. 5(2), 189-198 (2014)

8. E. Suganda, Y.A. Yatmo, P. Atmodiwirjo, Environmental Management and Community
Conditions in the Downstream Area of the River, Makara, Sos. Hum. 13(2), 143-153 (2009)

9. A.D. Tarlock, The Potential Role of Local Governments in Watershed Management, Pace 20(1), 149-176 (2003)

10. A. Dale, K. Vella, R. Potts, Governance Systems Analysis (GSA): A Framework for Reforming Governance Systems, J. Public Adm. Gov. 3(3), 162 (2013)

11. S. Jentoft, T.C.V. Son, M. Bjørkan, Marine protected areas: A governance system analysis, Hum. Ecol. 35(5), 611-622 (2007)

12. BPDAS, Bodri Integrated Watershed Management Plan (RPDAST), BPDAS Pemali Jratun - Semarang (2015) 